\title{
Business Strategy Formulation of Diamond Model of VSAT Internet Mangoesky Product (Case Study at Metrasat Division)
}

\author{
Bagus Putranto ${ }^{1}$, Heny Kuswanti $D^{2}$, Bunasor Sanim ${ }^{3}$ \\ ${ }^{1}$ Business School, Bogor Agricultural University, Jalan Raya Padjajaran, Bogor 16151, Indonesia \\ ${ }^{2}$ Department of Agribusiness, Faculty of Economics and Management, Bogor Agricultural University, Jalan Raya Darmaga, Bogor 16680, \\ Indonesia
}

${ }^{3}$ Department of Finance, Business School, Bogor Agricultural University, Jalan Raya Padjajaran, Bogor 16151, Indonesia

\begin{abstract}
The formulation of business strategy of VSAT Internet Mangoesky was measured by various methods such as Diamond method, SWOT and AHP analysis. The data obtained were processed by Expert Choice 11 software. Results of the formulation focused on the evaluation of Diamond's business strategy model are priority on Arena and Staging\&Pacing elements as Implementation of short or medium term of Mangoesky business strategy to increase sales as a new product. While the Differentiator and Vehicle elements are as long term products of development strategy to achieve an increase in profit of Economic logic element. The AHP analysis showed the alternative strategies are prioritized for each element of diamond models: The $1^{\text {st }}$ Priority Arena elements: Conducting market development and penetration in areas not yet reached by cable / GSM 3G signal. The $2^{\text {nd }}$ Priority on Staging and Pacing elements is "the acceleration deployment of hardware device and installations to achieve new link volume growth". On the $3^{\text {th }}$ Priority on Vehicle elements: "Cooperating with Vendor Satellite Operator and Hardware in product development and HR training". The $4^{\text {th }}$ Priority Differentiator elements by "Creating product image as the best solution for broadband Internet service in rural or sub urban area with best service quality In Indonesia”. And in the $5^{\text {th }}$ Priority Economic logic element that is "promotion program of quota bonus to increase internet data sale”.
\end{abstract}

Keywords: AHP, Diamond, Expert Choice, Mangoesky, SWOT, VSAT.

\section{Introduction}

The current development of digital technology makes people need internet data as daily basic needs. A study funded by UNICEF and implemented by the Ministry of Communications and Informatics (Kemkominfo) found that 98 percent of children and teenagers know about the internet and 79.5 percent of them are internet users (Az 2014). The following data from the survey results of APJII (Association of Indonesian Internet Service Providers) describes the penetration of Internet usage in Indonesia:

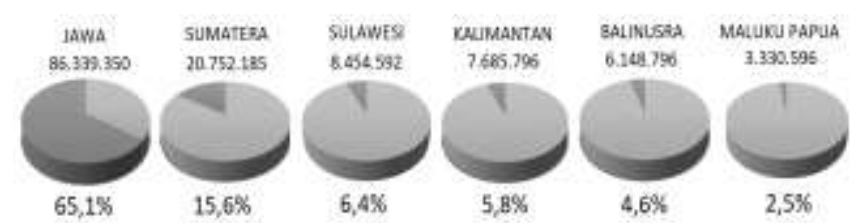

Figure 1: Survey of APJII 2016 the penetration of Internet usage in Indonesia.

The survey above shows the penetration of internet users in Indonesia is still not spread evenly, which is centered on Java island with 86.3 million to $65 \%$ of total 137.2 million users. As an effort to overcome the communication infrastructure gap and the lack of internet penetration in the Indonesian archipelago, especially rural and sub-urban areas, the Metrasat division (Telkommetra Ltd. the subsidiary of Telekomunikasi Indonesia Inc.) released VSAT (Very Small Appenture Terminal) with name of Product is Mangoesky in mid 2015. Mangoesky is a the first Indonesian High Speed satellite broadband internet access that reaches internet users in rural and sub-urban areas that are not yet reachable by cable and are the best solution for residentials, cafes, villas, small medium enterprises, industries and corporates.

VSAT Mangoesky as a new product is expected to develop as an innovation product that can increase the value and profitability of the company. But in its development, the company is still not maximum to get customers. Metrasat seeks to implement strategies to achieve the company's goals. To determine the right strategy in developing Mangoesky product, this study was done by adopting the concept of diamond strategy of Hambrick and Fredreckson (2001). The Diamond Strategy is a strategy used by big companies functioning to collect and consider all sections of the overall strategy by answering a series of related questions including arenas, vehicles, differentiators, staging and pacing and economic logic (Dianti 2014).

\section{Literature Review}

\subsection{Theories of Strategy}

The strategy-making process is the process of choosing and implementing strategies by managers to gain competitive advantages. Strategic leadership deals with managing the strategy-making process to improve the company's performance, which in turn will increase the value of the company for its owners (shareholders) in the form of profit. Therefore, the selection of strategies by utilizing competitive 


\section{International Journal of Science and Research (IJSR) \\ ISSN (Online): 2319-7064}

Index Copernicus Value (2016): 79.57 | Impact Factor (2015): 6.391

advantages is the right thing to do. Stages of the selection of strategies are known the formulation of strategies. Krawjesky and Ritzman (2002) define an operating strategy as a dimension that must be owned by a company's production system to support market demand. While, Flahtery (1996) defines the operating strategy as a corporate plan board or business unit to develop, introduce, and deliver products to satisfy customers' needs better than competitors. Both definitions contain customer orientation and competing weapon.

\subsection{Formulation of Strategies}

Schroeder (1989) defines an operating strategy as a vision of an operating function that sets the overall direction or driving force for decision making. This vision should be integrated with business strategy and reflected in formal planning but it is rarely to conduct. An operating strategy should result in a consistent pattern of operating decision making and lead to competitive advantage for the company. So it can be concluded that the concept and definition of operating strategy is as a company decision-making procedures to have leadership in manufacturing activities based on strategic perspective.

\section{Methodology}

The design of this study were case study of descriptive method, qualitative and semi quantitative analysis with object of Metratat division of Mangoesky business unit. This study was conducted at Metrasat Ltd. which is located in Bogor. The study was conducted from June to September 2017. The site selection was done purposively considering the study object is one of the business units that is considered and needed in Metrasat Ltd. This study used primary data from expert interviews and questionnaires. And for the secondary data are from company data and literature study. The study was conducted by using diamond model strategy, through interviews with expert sources at Metrasat who understand the mangoesky product business model.

Stages of processing and data analysis by: Firstly identified the business model of mangoesky products into 5 elements in diamond model: Arena, Vehicle, Differentiator, Staging and Pacing, and economic logic. Secondly analyzed internal and external factors using SWOT, what factors that could be considered in the implementation of Diamond Model Strategy that had been identified in mangoesky product, and from those factors alternative strategy through SWOT of each 5 Diamond element were developed. Lastly determined the priority strategy of the 5 elements of the diamond model and the alternative strategy of the SWOT matrix through the AHP questionnaire with pairwaise comparison.

\section{Research Result and Discussion}

\subsection{Diamond Model of Mangoesky Products.}

The results from observations and expert judgement interviews regarding the business model of Mangoesky product. Following 5 elements of the diamond model Arena,
Vehicle, Differentiators, Staging and pacing and Economic logic:

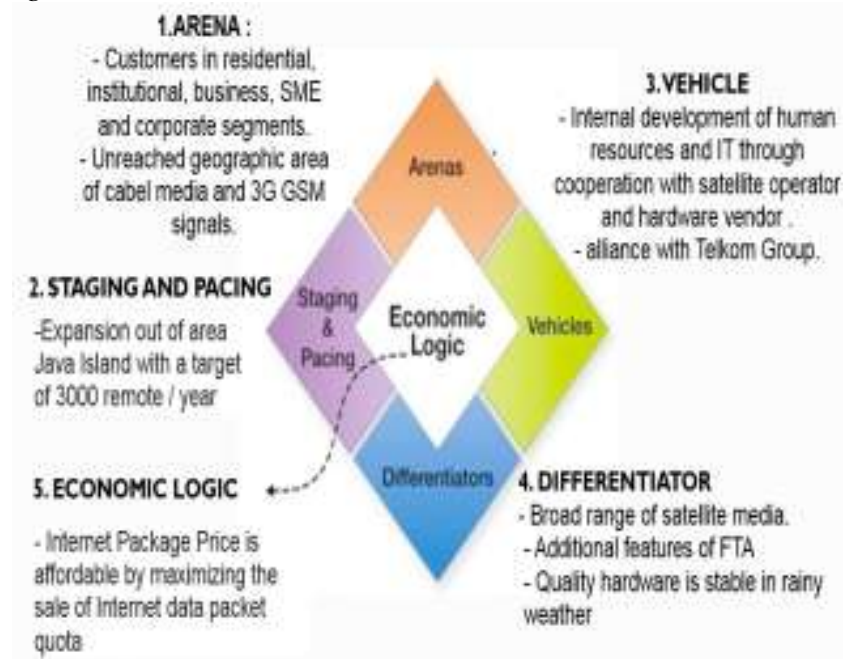

Figure 2: Identification diamond bussines model of Mangoesky Product.

The questionnaires were tested by AHP expert Choice resulted in the main priority data of business strategy formulation. Based on Figure 3, the factors that became the main priority as formulation of business strategy was Arena with weight value of 0.396 . The second priority was Staging \&pacing element of 0.214 , the third priority was Vehicle of 0.158 , the fourt was the Differentiator of 0.129 and the fifth was Economic logic of 0.103 .

\section{Priorities with respect to:}

Arena
Staging \& Pacing
Vehicle
Differentiators
Economic Logic
Inconsistency $=0.00477$

Combined

with 0 missing judgements.

Figure 3: AHP result of formulation diamond elements.

The result of AHP from 5 element diamond indicated the priority of Arena element and staging \& Pacing very dominated. So it is quite clear the priority of the expansion strategy becomes the main choice to develop mangoesky products As a new product Innovation that is new to the market. Market development strategy and market penetration can be implemented especially in outside Java area to fulfill internet requirement which have not covered by cable media and GSM signal.

\subsection{SWOT factors: the strengths and weaknesses of Mangoesky products}

The data of SWOT analysis on Internal or external environment in this study were obtained from the interview process by competent expert resources in the field of satellite business provider. The level of importance of the factors and their numbers were grouped by 5 elements Priority of the diamond model strategy that had been formulated. The 10 


\section{International Journal of Science and Research (IJSR) \\ ISSN (Online): 2319-7064}

Index Copernicus Value (2016): 79.57 | Impact Factor (2015): 6.391

internal strength factors and 5 internal weakness factors from VSAT internet Mangoesky can be seen in table 1:

Table 1: Internal factors Strengths and Weakness

\begin{tabular}{|c|c|}
\hline Strength Factors $(\mathrm{S})$ & Weakness Factors (W) \\
\hline \multicolumn{2}{|c|}{$*$ ARENA } \\
\hline \multicolumn{2}{|c|}{ arge range of satellites cover the New product that has not been } \\
\hline $\begin{array}{l}\text { The Pioneer Products Broadband } \\
\text { internet service via satellite. }\end{array}$ & \\
\hline \multicolumn{2}{|c|}{ *STAGING AND PACING } \\
\hline $\begin{array}{l}\text { Large VSAT Hub Capacity for } \\
\text { new remote customers. }\end{array}$ & $\begin{array}{c}\text { Slow hardware delivery as still } \\
\text { centralized Bogor Operational } \\
\text { Office.s. }\end{array}$ \\
\hline $\begin{array}{l}\text { upports from operational division } \\
\text { and fast service delivery in } \\
\text { installation. }\end{array}$ & \\
\hline \multicolumn{2}{|l|}{ *VEHICLE } \\
\hline $\begin{array}{l}\text { Expert technicians and engineers } \\
\text { (HRD) in satellite }\end{array}$ & $\begin{array}{c}\text { The lack number of marketing } \\
\text { and technical personnel of } \\
\text { VSAT in rural areas. }\end{array}$ \\
\hline $\begin{array}{l}\text { 6.Division of the subsidiary of } \\
\text { Telkom Indonesia Inc }\end{array}$ & \\
\hline \multicolumn{2}{|c|}{ *DIFFERENTIATOR } \\
\hline $\begin{array}{c}\text { Broadband Internet service with } \\
\text { HTS (High Troughput Satellite) } \\
\text { and with wide range. }\end{array}$ & $\begin{array}{c}\text { Delay Satellite transmission is } \\
\text { slow compared to media Cable } \\
\text { and GSM Access above } 600 \\
\text { ms }\end{array}$ \\
\hline $\begin{array}{l}\text { Sets of qualified hardware with } \\
\text { modern and up to date VSAT } \\
\text { KU band technology. }\end{array}$ & \\
\hline *ECONOMIC LOGIC & \\
\hline $\begin{array}{l}\text { 9. Cash and healthy corporate } \\
\text { finance to support operational. }\end{array}$ & $\begin{array}{l}\text { The price of hardware which is } \\
\text { relatively high. }\end{array}$ \\
\hline $\begin{array}{l}\text { Good corporate management in } \\
\text { managing the company's } \\
\text { operations. }\end{array}$ & \\
\hline
\end{tabular}

\subsection{External opportunities and threats of VSAT internet Mangoesky.}

SWOT analysis on the external environment is important to consider in the implementation of the diamond strategy model because the external environment is more difficult to control. Here are the results of the identification of external factors in 5 elements of diamond strategy, that there are 10 opportunity factors and 7 barrier factors of Mangoesky Product that can be seen in Table 2 .

Table 2: External factors Opportunities and Threats

\begin{tabular}{|c|c|}
\hline No. $\quad$ portunities Factors (O) & Threaths Factors (T) \\
\hline \multicolumn{2}{|c|}{ *ARENA } \\
\hline $\begin{array}{c}\text { Inequality of Internet Network } \\
\text { Infrastructure in Indonesia. }\end{array}$ & $\begin{array}{c}\text { Development of internet cable / } \\
\text { Fiber and 3G GSM signals in the } \\
\text { existing customer area. }\end{array}$ \\
\hline $\begin{array}{c}\text { 2. PT.Telkom's project with } \\
\text { government internet fulfillment in } \\
\text { rural areas. }\end{array}$ \\
\hline \multicolumn{2}{|c|}{ *STAGING AND PACING } \\
\hline $\begin{array}{c}\text { Plenty of Location Outside Java } \\
\text { islands Out of reach 3G cable and } \\
\text { signal. }\end{array}$ & $\begin{array}{c}\text { The entry of new competitors } \\
\text { VSAT broadband Internet } \\
\text { products in the area outside of } \\
\text { Java island. }\end{array}$ \\
\hline $\begin{array}{c}\text { 4. The potential of centralized } \\
\text { ordering thousands of remote }\end{array}$ & \\
\hline
\end{tabular}

\section{links in Government and \\ Corporate Institutions Project outside Java. \\ *VEHICLE}

Coverage Area WITEL (Regional Location of VSAT installation Office Telkom) spread throughout which is far from the reach of Indonesia. transportation facilities.

Offers cooperation with satellite

operators and Vendoor hardware International quality

\section{*DIFFERENTIATOR}

nternet data service needs in rural ack of Product knowledge of the areas that have not reached cable User regarding VSAT network and $3 \mathrm{G}$ signal. devices and Top up systems.

There are not many competitors limate in Indonesia High rainfall among VSAT providers and VSAT-prone interference with Frequency KU band.

\section{*ECONOMIC LOGIC}

Recurring Income from increased High costs of transportation and customer volume. shiping in rural areas.

10. Revenue from sales top up 7.Device loss or damage, and internet data quota operations.

withdrawal fee upon termination of subscription

From the SWOT Analysis of the Internal and External Environment that has been identified, these factors can be considered for determining alternative strategies through the SWOT Matrix tool.

\subsection{The results of alternative strategies using the SWOT Matrix.}

Analysis is used as direction in making strategy and work program of a company (Nainggolan 2011). If an element changes then all elements will change following that change (Tang 2014). Core competence is an activity that really contributes to the company in the long term (Usman 2013).

Implementation of a business model with a diamond strategy approach on Mangoesky products requires an alternative strategy, whereby this strategy is solved from matching internal and external factors in each of the five elements in the diamond model. The following alternative strategies are generated from the SWOT matrix tool will be create (SO) strategies using the power they have to gain opportunities,(ST) strategies use the power to avoid and overcome threats, (WO) strategies use opportunities to overcome weaknesses and (WT) strategies to minimize weaknesses and avoid threats.

Based on Figure 4, it can be seen the factor that became the priority of alternative strategy based on the arena element was that (SO1) Arena $_{\text {Performs market development and }}$ penetration in areas that have not been reached by the cable / $3 \mathrm{G}$ signal with the weight value of 0.500 . Business strategy on study (Faruq and Usman 2014) shows that product development strategy for variety and product design with product innovation strategy was very important. The second priority is (ST1) ${ }_{\text {Arena }}$ with the weight value of 0.213 which is to perform projection mapping of geographic region potential market for VSAT media.

\section{Volume 6 Issue 12, December 2017}




\section{International Journal of Science and Research (IJSR) \\ ISSN (Online): 2319-7064}

Index Copernicus Value (2016): 79.57 | Impact Factor (2015): 6.391

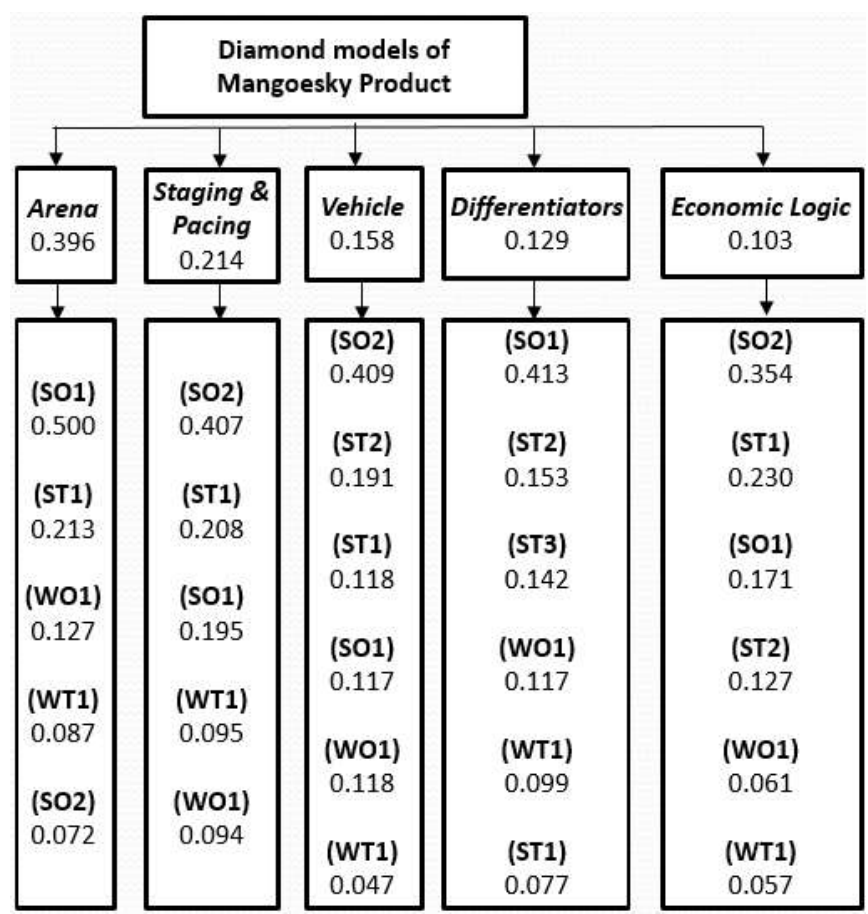

Figure 4: AHP weight score results of alternative strategy priority on the SWOT matrix.

The alternative strategy based on Staging and Pacing element was (SO2) $)_{\text {staging and Pacing }}$ with the weight of 0.407 that was to accelerate device deployment and installation to achieve growth target of new link volume. The second priority was (ST1) staging and Pacing with the weight of 0.208 that was to accelerate the development of potential new markets beyond Java Island.

The priority weight of the alternative business strategy based on the Vehicle element is shown in Figure 4 that the priority factor of the strategy based on the vehicle element was that (SO2) vehicle did cooperation with Vendoor Satellite Operator and Hardware in product development and HRD training with the weight value of 0.409 . The second priority was (ST2) Vehicle : Forming of cadres of VSAT Expert from center to potential customer areas with weight value 0.191. The service adds to the company's reputation, so sales will automatically increase (Fenno 1992).

The priority factor of alternative strategy based on Differentiator element was (SO1) Differentiator with weight value of 0.413 that was to create product image as the best solution of broadband Internet service in rural or sub urban areas with the best service quality. The second priority was (ST2) Differentiator with the weight value of 0.153 that was to guarantee good network quality to customers by providing service 24-Hour Customer care for handling problems. A good strategy in the environment will lead to a decrease in competition (Hoefter 2001). The need to invest large investments in order to compete creates entry barriers, especially if the capital is used for advertising, research and development activities (Setiawan 2011).

SWOT matrix was combined with Economic logic element, it showed the priority factor of strategy based on weight value was (SO2) Economic logic with the quota bonus promotion program to increase internet data sales. The second priority was (ST1) ) Economic logic with the weight of 0.230 that the efficiency of shipment cost by cluster cost and minimum order limit based on distance of region.

\subsection{The Discussion}

The increasing number of internet users and internet access providers (ISPs) in Indonesia makes Internet interconnection providers (NAPs) compete to meet and offer internet interconnection services and international internet bandwidth at competitive prices (Setiawan 2011). A study conducted by Nurcahyono et al. 2013 used Five Porters analysis which aimed to see the competitive level of VSAT Kuband products explains that VSAT Kuband product prospect is quite competitive with middle value.

The strategy formulation in this study only prioritized on how diamond model strategy can be implemented to develop Mangoesky product without calculating the value of investment or influence from the financial aspect of the company. Therefore it is necessary to conduct further study by taking into account aspects of finance, cost and investment. It also needs to conduct study that involves more customer participation, eg survey mangoesky customers to increase the value and know the customer perception on the product Mangoesky and Division Metrasat.

It is clear that the mobile telecom market will make it more competitive and make the operators stronger and then form a strategy to keep the market and survive sustainably (Gkloumpou 2013). Prajunianto and Titus (2013) undertook a study to determine Bakrie Telecom's business strategy to increase profit from internet data business with business model canvas and Diamond strategy analysis as it research tools.

There are seven factors which cause the decline of the company's performance, namely unclear product position, immature market segment, geographical area that are not yet optimal, technology that is not yet developed, the development of HRD is stopped, product design is not unique, and product quality is unstable (Yuharmelia 2015). Business strategy on study of Faruq and Usman 2014 showed that product development strategy for variety and product design with product innovation strategy are very important.

\section{The Conclusion}

Here are the conclusions from research :

1) The importance of focusing on the evaluation of Diamond's business strategy model with priority on Arena and Staging \& Pacing elements as the Implementation of short or medium term Mangoesky business strategy. While the Differentiator and Vehicle elements as longterm product development strategy to achieve elements of Economic logic.

2) Fixed Internal factor of weakness that can be controlled, that is slow delivery of device because still centered in Bogor. External factors that cannot be controlled become 


\section{International Journal of Science and Research (IJSR) \\ ISSN (Online): 2319-7064}

Index Copernicus Value (2016): 79.57 | Impact Factor (2015): 6.391

important factors to note on element of Arena that is the main threat is development of area of cable network and GSM which must be avoided.

3) The priority strategy in marketing Mangoesky products by doing Alternative Strategy:

In the Arena element as first priority :

- Market development outside Java, especially areas that have not reached the media cable and 3G GSM signal.

- Penetration in the existing area of subscribers by conducting ad campaign activities in various media and internet data quota bonus programs.

In the Staging and pacing element as a second priority:

- Accelerate Deployment of hardware devices and installations for growth of new customer VSAT link volumes with target of 3000 remote every year.

\section{References}

[1] Az.2014. 98 Persen Anak dan Remaja Tahu Internet. [Internet] [downloaded October $10^{\text {th }}$ 2017]. Available on: www. Kominfo.go.id

[2] Dianti F. 2014. Penerapan diamond strategy pada usaha kecil dan menengah di Surabaya. [Internet] [diunduh 2017 Oktober 10]. Tersedia pada : http://repository.unair.ac.id/53

[3] Faruq MA, Usman I. 2014. Penyusunan Strategi bisnis dan strategi operasi usaha kecil dan menengah pada perusahaan konveksi scissors di Surabaya. Journal of Manajemen Teori dan Terapan. 7 (3): 173-198.

[4] Flahrety T, 1996. Global Operation Management. United State (US): McGraw Hill International Edition.

[5] Fenno B. 1992. Strategi bisnis penunjang pertumbuhan usaha anda. Jakarta (ID): Dahara Prize. Nasution M. 2004. Manajemen Jasa Terpadu. Bogor (ID) : Ghalia Indonesia.

[6] Gkloumpou E. 2013. Analysis and interpretation of competitive strategies and consumer behaviour using ComScore online panel data. [thesis]. Jakarta(ID): School of Computer Science.

[7] Hambrick DC, Fredrickson JW. 2001. Are you sure you have a strategy?. The Academy Management Executive. 15(4): 48-59.

[8] Hoefter A. 2001. The Competitiveness of Ghana's Industry. [dissertation]. Difo-Druck GmbH, Bamberg. Swiss(CE): Universität St.Gallen.

[9] Krawjesky, L.J., \& Ritzman, L.P. 2002. Operation Management: Strategy and Analysis, Sixth Edition, Prentice Hall International, Inc

[10] Nainggolan EDH. 2011. Strategi peningkatan daya saing untuk meningkatkan profit perusahaan jasa konstruksi (Kontraktor) studi kasus rekanan PT. X. [thesis]. Jakarta (ID): University of Indonesia.

[11] Nurcahyono, Segoro W, Bakara MYV. 2013. Strategi pemasaran produk VSAT Kuband pada layanan internet dengan pendekatan analisa five Porters dan fuzzy SWOT. Jurnal Telekomunikasi dan Komputer. 4(2): 174-192. doi: 10.22441/incomtech.v4i2.1130.

[12] Prajunianto, Titus A. 2013. Determining Bakrie Telecom's business strategy to boost the revenue from internet data business. IJBA. 2(11): 1234-1247.
[13] Setiawan W. 2011. Analisis strategi meningkatkan layanan NAP di dalam industri telekomunikasi (Studi kasus : PT Indonesia Comnets Plus). [thesis]. Jakarta(ID): University of Indonesia.

[14] Schoroeder, Roger R., 1989. Operation Management: Decision Making in the Operation Function, McGraw Hill - Internasional Edition.

[15] Tang PSZ. 2014. Redefinition of transport sharing system for a sustainable future. Sweden (SE): Management \& Economics Chalmers university of technology Gothenburg.

[16] Usman H. 2013. Manajemen Teori, Praktik, dan Riset Pendidikan. Ed ke- 4. Jakarta (ID): Bumi Aksara

[17] Yuharmelia I. 2015. Strategi Untuk Bisnis Yang Menurun Dengan Pendekatan Strategi Diamond Studi Pada Hasan Batik Bandung. [thesis]. Yogyakarta (ID): Gajah Mada University.

\section{Author Profile}

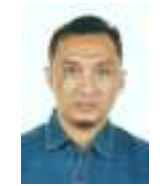

Bagus Putranto received the B.S. degrees in Economic Management, Surabaya Airlangga University in $2009 \mathrm{He}$ is now a master candidate of School of Business and Management of Bogor Agriculture University. 